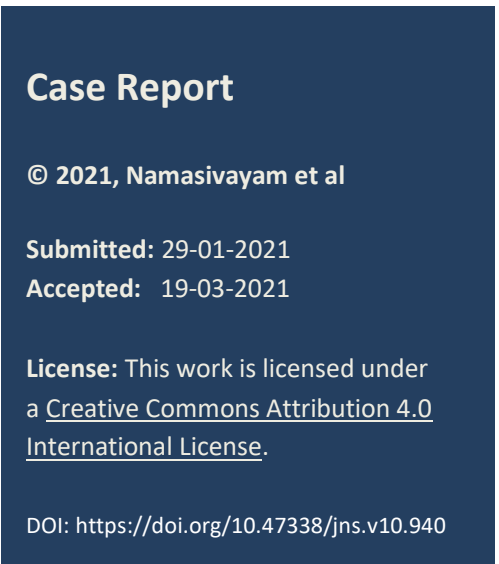

\title{
Tracheoesophageal fistula with complex injury to the existing anomaly - Youngest neonate to survive: A case report
}

Selvarajan Namasivayam, ${ }^{*}$ Natarajan Chandra Kumar, Singaravelu Ramesh, Vijayakumar Vanathi, Muthukrishnan Saravana Balaji, Mokrala Naga Srinivasa Uday Bhaskar, Akhtarkhavari Anis

Kanchi Kamakoti CHILDS Trust Hospital, 12A Nageswara Road, Nungambakkam, Chennai 600034, India

Correspondence*: Dr. Namasivayam Selvarajan, Department of Pediatric Surgery, Kanchi Kamakoti CHILDS Trust Hospital, 12A Nageswara Road, Nungambakkam, Chennai 600034, India. E-mail: dr.namasivayam@gmail.com

\section{KEYWORDS \\ Esophageal atresia, \\ Tracheoesophageal fistula, \\ Neonate, \\ Preterm, \\ Tracheoesophageal trauma}

\begin{abstract}
Background: Complex injury to the esophagus, trachea, and tracheoesophageal fistula in a case of esophageal atresia is rarely reported that requires prompt identification and management.
\end{abstract}

Case Presentation: A very-low-birth-weight preterm with a tracheoesophageal fistula on ventilatory support for respiratory distress syndrome was transferred to our hospital. The baby developed air-leak through the tracheoesophageal fistula into the stomach causing gross distension of the stomach and reduction in oxygen saturation. Repositioning and reintubation failed to reduce the abdominal distension and to improve the saturation. Subsequent intubation with large volume, low pressure cuffed tube, and replacement of Replogle tube resulted in pneumothorax and further deterioration requiring emergency thoracotomy. Complex tracheoesophageal injury to the esophagus, trachea, and fistulous tract was repaired.

Conclusion: The baby survived the early repair of the tracheoesophageal fistula and the iatrogenic complex tracheoesophageal injury. Pre-operative tracheo-esophagoscopy with stenting of the fistula with Fogarty catheter helped to carry out a successful repair technically.

\section{INTRODUCTION}

Esophageal atresia (EA) is one of the most common life-threatening congenital anomalies of the newborn and occurs in 2.44 in 10,000 births. The current survival rate of EA with Tracheoesophageal fistula (TEF) in term neonates with birth weight more than $>2500$ gm - normal birth weight (NBW) and $>1500 \mathrm{~g}$ to $<2500$ g - low birth weight (LBW), without major congenital cardiac anomaly, is 95\% and can be achieved with early primary repair.[1] The very low birth weight (VLBW) babies (>1000 g to $<1500 \mathrm{~g}$ ) had poor survival with a mortality ranging from $100 \%$ in the early fifties to $20 \%$ in the late nineties which was attributed to intrauterine growth retardation, respiratory distress syndrome (RDS), associated anomalies, cardiopulmonary vulnerability, necrotizing enterocolitis, intracranial hemorrhage, and immature immune system.[2] Since the late nineties, the survival in this group has increased to $87 \%$.[3] VLBW babies with EA are more commonly associated with isolated EA (10\%) than EA with TEF. VLBW babies with isolated EA have better survival. VLBW babies with EA and TEF are a special group because of the intrauterine growth retardation, related RDS, the risk of gross air-leak through the fistula into the stomach, and its complication- the gastric perforation, which carries a mortality rate as high as 70\%.[2] The iatrogenic injuries caused during the preoperative period of management in preterm babies with TEF are uncommon, lifethreatening, under-recognized, and had poor survival. This report is about a baby belonging to such a special group resulting in a gross air leak and cardiovascular collapse requiring repositioning of the endotracheal tube (ETT). Several attempts to replace ETT, suctioning, and replacement of Replogle tube resulted in complex tracheoesophageal trauma and pneumothorax

\section{CASE REPORT}

A preterm female baby born by emergency LSCS for decreased fetal movements at 32 weeks weighing 1.1 
kg with EA/TEF was transported on ventilatory support to our institution at three days of age. The baby developed poor chest rise, desaturation, and bradycardia due to a large air leak into the stomach through the fistula. Initial attempts by adjusting the position of the ETT failed. Further attempts by changing the ETT and subsequently with a large volume low pressure cuffed tube as well as replacing the Replogle tube ended up in pneumothorax (Fig.1).
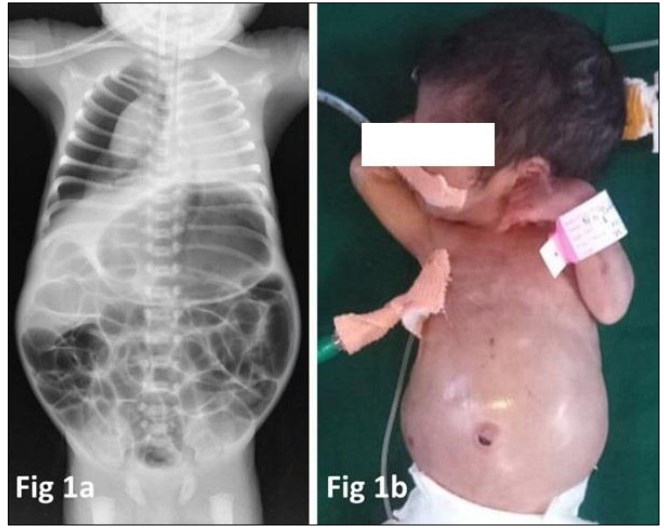

Fig.1a. Right pneumothorax with grossly distended stomach with splinting of diaphragm and Fig. $2 \mathrm{~b}$. Intubated neonate with grossly dilated stomach and Rt ICD.

Intercostal drainage (ICD) was inserted, and the baby was shifted to OR for emergency surgery. Preoperative laryngo-tracheoscopy (PLT) showed a fistulous opening at the usual site proximal to the carina. The opening was wide and the edges were irregular suggestive of trauma (Fig.2a,2b \& 2c). A Fogarty catheter was introduced into the fistulous opening and the balloon was placed in the stomach, which was verified by fluoroscopy (Fig.2d).

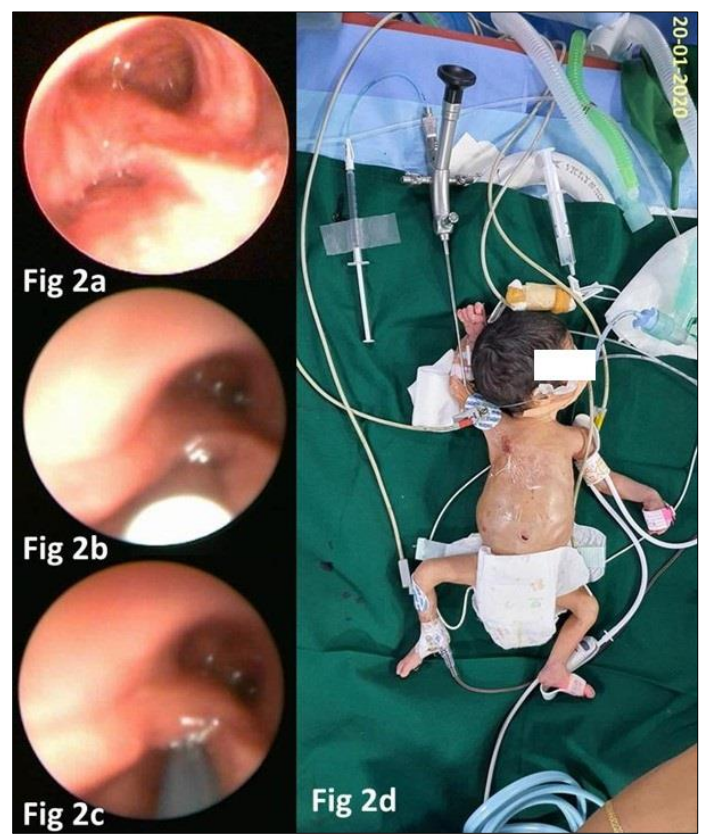

Fig.2a. LTS showing wide fistula opening with irregular edges showing trauma, Fig.2b. Fogarty catheter tip is being negotiated into the fistula and Fig.2c. Well placed Fogarty catheter through the fistula.Fig.2d. Cystoscope with offset lens used for LTS and the Fogarty catheter stent passed through the fistula into the stomach.
PLT with a cystoscope with an offset lens and placement of Fogarty catheter has been routinely carried out by us for the last five years.[4] Right posterolateral thoracotomy by trans-pleural approach was carried out. The feeding tube passed into the upper pouch at the time of induction replacing the Replogle tube had come out through a tear in the upper pouch into the pleural cavity. The fistula was torn along its entire length except for a sliver of tissue medially holding the trachea and the lower pouch exposing the Fogarty catheter. The endotracheal tube could be seen through a tear extending into the trachea from the proximal end of the fistula (Fig.3a). After a careful dissection with the help of the exposed stent which was seen bridging across the tracheal end of the fistula and lower pouch through the torn fistulous tract, the remaining fistulous tract was disconnected from the trachea, and the lower pouch and was excised. The fistulous opening and the adjacent tear on the trachea were closed. The torn tissues of the lower end of the upper pouch were trimmed. The anastomosis of the upper and lower pouches was carried out with slight tension (Fig.3b).

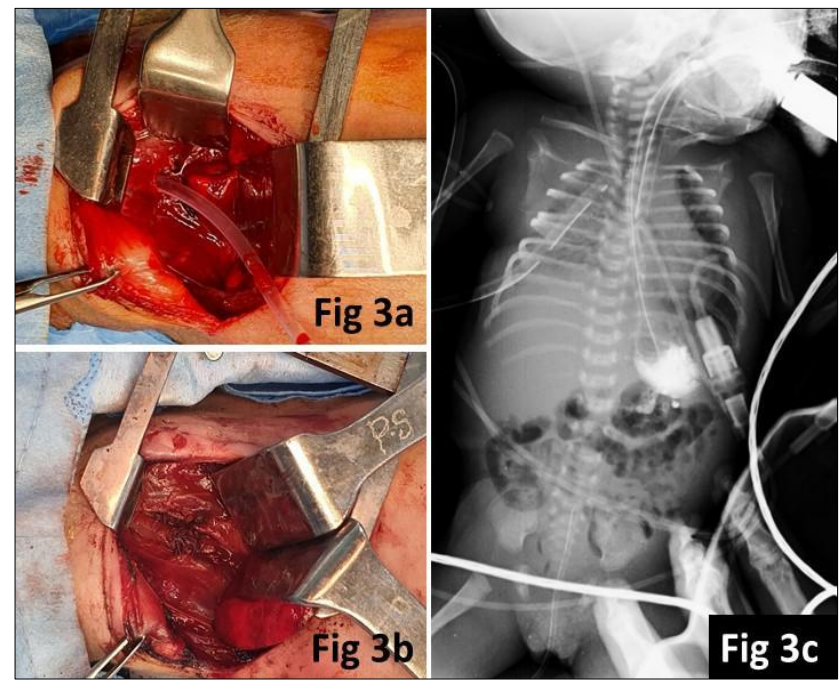

Fig.3a. Complex tracheo-esophageal trauma with the NG tube seen lying in the pleural cavity through the rent in the upper pouch, Fig.3b. Repair of the tracheo-esophageal trauma and the primary repair and Fig.3c. No leak in the post-operative esophagogram.

To tide over the tension at the anastomosis, a trans anastomotic nasogastric 8F Silastic Foley balloon catheter was placed as a stent. The balloon inside the stomach was inflated and gentle traction was given at the nasal end of the Foley catheter till a slackness was felt at the anastomosis and the catheter was fixed to the nose. This technique to reduce the tension at the anastomosis has been used by us for the last 10 years.[5] There was no leak in the postoperative contrast esophagogram (Fig.3c). The baby required prolonged CMV and TPN. The baby was discharged at the age of 4 months with adequate weight $(2.94 \mathrm{~kg})$ for the age and normal oral feeding and is doing well 14 months after the surgery. 
Table 1: Cases of iatrogenic tracheoesophageal injury in EA with or without TEF

\begin{tabular}{|c|c|c|c|c|c|c|c|}
\hline Year / Author & $\begin{array}{l}\text { Age / EA type / } \\
\text { Age of onset of } \\
\text { symptoms }\end{array}$ & $\begin{array}{l}\text { Site of perfo- } \\
\text { ration }\end{array}$ & Cause & $\begin{array}{l}\text { Aggressive } \\
\text { non-surgical } \\
\text { methods }\end{array}$ & $\begin{array}{l}\text { Type of } \\
\text { repair }\end{array}$ & $\begin{array}{l}\text { Surgical proce- } \\
\text { dures }\end{array}$ & $\begin{array}{l}\text { Survival / } \\
\text { Death }\end{array}$ \\
\hline $\begin{array}{l}1978 \text { Wright } \\
\text { VM [11] }\end{array}$ & $\begin{array}{l}\text { LWB } 1800 \mathrm{~g} 34 \\
\text { wks. } \quad \text { TEF Type } \\
\text { C. } \quad 18 \\
\text { Hours of life. }\end{array}$ & Upper pouch & $\begin{array}{l}\text { Replogle Plastic } \\
\text { sump catheter }\end{array}$ & Nil & $\begin{array}{l}\text { Staged } \\
\text { surgery }\end{array}$ & $\begin{array}{l}\text { Gastrostomy, } \\
\text { Thoracotomy - } \\
\text { Fistula ligation, } \\
\text { Cervical esoph- } \\
\text { agostomy }\end{array}$ & Survived \\
\hline $\begin{array}{l}1986 \text { McLeod } \\
\text { BJ [9] }\end{array}$ & $\begin{array}{l}\text { Preterm, } \\
\text { LBW,1600 g. } \\
\text { TEF Type C Day } \\
1\end{array}$ & $\begin{array}{l}\text { Trachea at the } \\
\text { level of fistula }\end{array}$ & $\begin{array}{l}\text { Cole's tracheal } \\
\text { tube } 3 \mathrm{~mm} \text { (Thick) } \\
\text { without stylet }\end{array}$ & Nil & $\begin{array}{l}\text { Staged } \\
\text { Surgery }\end{array}$ & $\begin{array}{l}\text { Ligation of fistula } \\
\text { and gastrostomy }\end{array}$ & Died. \\
\hline $\begin{array}{l}2013 \text { Acker } \\
\text { SN [12] }\end{array}$ & $\begin{array}{l}\text { ELBW, } 755 \mathrm{~g} \text {, } \\
\text { TEF Type C. Day } \\
2 \text { of life }\end{array}$ & $\begin{array}{l}\text { Upper pouch } \\
\text { and Isolated } \\
\text { ileal perfora- } \\
\text { tion }\end{array}$ & Orogastric tube & Nil & $\begin{array}{l}\text { Primary } \\
\text { anastomo- } \\
\text { sis }\end{array}$ & $\begin{array}{l}\text { Thoracotomy - } \\
\text { Primary esophageal } \\
\text { anastomosis and } \\
\text { gastrostomy. }\end{array}$ & $\begin{array}{l}\text { Alive and } \\
\text { thriving }\end{array}$ \\
\hline $\begin{array}{l}2013 \text { Parelkar } \\
\text { S [13] }\end{array}$ & $\begin{array}{l}\text { VLBW } \\
1400 \mathrm{~g} . \text { Pure } \\
\text { EA. Day } 3 \text { of } \\
\text { life }\end{array}$ & Upper pouch & $\begin{array}{l}\text { Stiff } 10 \mathrm{~F} \text { rubber } \\
\text { catheter used for } \\
\text { contrast study of } \\
\text { upper pouch }\end{array}$ & Nil & & $\begin{array}{l}\text { Cervical esoph- } \\
\text { agostomy and feed- } \\
\text { ing gastrostomy } \\
\text { without thoracotomy }\end{array}$ & $\begin{array}{l}\text { Results not } \\
\text { mentioned }\end{array}$ \\
\hline $\begin{array}{l}2018 \text { Dwivedi } \\
\text { D [14] }\end{array}$ & $\begin{array}{l}\text { VLBW } 1500 \\
\text { g. TEF Type C. } \\
\text { Early Primary } \\
\text { repair. }\end{array}$ & $\begin{array}{l}\text { Posterior } \\
\text { pharyngeal } \\
\text { wall }\end{array}$ & $\begin{array}{l}\text { NG tube insertion } \\
\text { for identification } \\
\text { of upper pouch }\end{array}$ & Nil & $\begin{array}{l}\text { Primary } \\
\text { anastomo- } \\
\text { sis }\end{array}$ & $\begin{array}{l}\text { Anastomosis com- } \\
\text { pleted. Postextuba- } \\
\text { tion apnea, Reintu- } \\
\text { bated. }\end{array}$ & Died. \\
\hline
\end{tabular}

\section{DISCUSSION}

The survival of VLBW babies has improved in recent years. This improved survival is related to the consideration of early primary repair in stable cases and delayed esophageal anastomosis or staged surgery in unstable cases, availability of endotracheal intubation, and advances in neonatal, respiratory, surgical, and anesthetic care. There are controversies in the method of management of the VLBW babies with EA and TEF between primary repair and delayed primary anastomosis and staged surgery among the institutions. $[2,3,6]$

VLBW babies with EA with TEF are a special group and may require methods of surgical management other than the primary anastomosis which was first performed by Haight in 1943. This group is considered special because of the intrauterine growth retardation, related $\mathrm{RDS}$, and the risk of progressive atelectasis, loss of functional residual capacity, increased pulmonary vascular resistance, and frequent requirement of continuous mechanical ventilation (CMV). High pressures in the pulmonary parenchyma and the relatively lower pressure of the fistula creates a ventilatory leak through the TEF. This worsens the respiratory distress secondary to the loss of ventilation and resultant gastric distension leading to cardiovascular collapse and gastric perforation which carries a mortality rate as high as $70 \%$.[2,7] The aggressive non-surgical methods adopted to tackle the air leak through the fistula into the stomach before surgical correction are positioning of ETT tip distal to the fistulous opening, positioning with affected side down, placement of Fogarty catheter either by bronchoscopy or by laparotomy to occlude the fistula with the balloon, banding of the esophagus, gastric division, nee- dle paracentesis of the abdomen, high-frequency ventilation, ECMO, and gastrostomy with underwater seal. The results of these procedures are unreliable, less consistent, and time taking than the emergency fistula ligation which gives an opportunity to carry out primary repair also.[7] Isolated iatrogenic tracheal or bronchial injury has been reported in 15 neonates.[6] Death usually occurs at the time of injury but in rare cases where the baby survives, the conservative methods showed higher mortality (88\%) than that for the surgical treatment (55\%).[7] Thirtysix cases of GI perforations related to air leak published since 1980, shows overall mortality of $50 \% .[7,8,10]$ Iatrogenic injuries caused during the management of this special group of VLBW babies with TEF had brought poor survival in the past (Table 1). [9-14] The sites of injury in these 5 cases were the upper pouch in 3 , posterior pharyngeal wall in 1 , and trachea at the level of fistula in 1 . The case presented had a complex tracheoesophageal injury involving the upper pouch, trachea, and fistula which has not been published. Aggressive non-surgical management of air-leak resulted in this injury. Emergency thoracotomy, repair of the injury gave an opportunity to carry out a primary repair. The baby survived the prolonged ventilatory support required for the lung hypoplasia of prematurity. Such special groups of VLBW babies with TEF are advised to be managed on the following lines. 1. Emergency thoracotomy and primary repair before the complications of RDS sets in. 2. If the complications set in very early after birth, emergency thoracotomy, fistula ligation, and primary anastomosis should be attempted and 3. In cases unstable after the fistula ligation, delayed primary anastomosis or staged repair can be planned. 
Acknowledgements: Nil

Conflict of Interest: Authors have no conflict of interest.

Source of Support: Nil

\section{REFERENCES}

1. Hollwarth ME, Till H. Oesophageal atresia. In: Puri P, editor. Pediatric Surgery General principles and Newborn Surgery, 1st ed, Berlin: Springer-Verlag; 2020. p. 661-680.

2. Chahine AA, Ricketts RR. Esophageal atresia in infants with very low birth weight. Semin Pediatr Surg. 2000; 9:73-8

3. Chee YY, Wong MS, Wong RM, Wong KY. Neonatal outcomes of preterm or very-low-birth-weight infants over a decade from Queen Mary Hospital, Hong Kong: comparison with the Vermont Oxford Network. Hong Kong Med J. 2017; 23:381-6.

4. Namasivayam S. Comprehensive preoperative airway assessment in tracheo-oesophageal fistula (TEF) In: Gupta P (Ed). Abstract book of 43rd Annual Conference of Indian Association of Paediatric Surgery: 21-24 September 2017.

5. Namasivayam S. Foley catheter stent for TEF repair - A preliminary study In: Pavai A (Ed). Abstract book of Annual Conference of Tamilnadu \& Pondicherry State chapter of IAPS: July 2012.

6. Seitz G, Warmann SW, Schaefer J, Poets CF, Fuchs J. Primary repair of esophageal atresia in extremely low birth weight infants: a single-center experience and review of the literature. Biol Neonate. 2006; 90:247-51.

7. Gien J, Ing RJ, Twite MD, Campbell D, Mitchell M, Kinsella JP. Successful surgical management of airway perforation in preterm infants. J Pediatr Surg Case Rep. 2014; $2: 47-51$.
Consent to Publication: Author(s) declared taking informed written consent for the publication of clinical photographs/material (if any used), from the legal guardian of the patient with an understanding that every effort will be made to conceal the identity of the patient, however it cannot be guaranteed.

Author Contributions: Author(s) declared to fulfil authorship criteria as devised by ICMJE and approved the final version.

8. Templeton JM Jr, Templeton JJ, Schnaufer L, Bishop HC, Ziegler MM, O'Neill JA Jr. Management of esophageal atresia and tracheoesophageal fistula in the neonate with severe respiratory distress syndrome. J Pediatr Surg. 1985; 20:394-7.

9. McLeod BJ, Sumner E. Neonatal tracheal perforation. A complication of tracheal intubation. Anaesthesia. 1986; 41:67-70.

10. Rathod KK, Bawa M, Mahajan JK, Samujh R, Rao KL. Management of esophageal atresia with a tracheoesophageal fistula complicated by gastric perforation. Surg Today. 2011; 41:1391-4.

11. Wright VM, Noblett HR. A complication of continuous upper pouch suction in esophageal atresia. J Pediatr Surg. 1978; 13:369-70.

12. Acker SN, Bansal S, Somme S. A 25 weeks gestational age, $755 \mathrm{~g}$ neonate with esophageal atresia and tracheoesophageal fistula presents with ileal perforation and esophageal pouch perforation. Journal of Pediatric Surgery Case Reports. 2013; 1:395-7. Available from: https://doi.org/10.1016/j.epsc.2013.10.009.

13. Parelkar S, Mundada D, Joshi P, Sanghvi B, Kapadnis $\mathrm{S}$, Oak S. Iatrogenic perforation of upper pouch in pure esophageal atresia: a rare complication and review of literature. European J Pediatr Surg Rep. 2013; 1:21-3.

14. Dwivedi D, Makkar J, Sharma R, Jafra A. Pneumomediastinum following iatrogenic pharyngeal perforation during tracheoesophageal fistula repair. Saudi J Anaesth. 2018; 12:355-7. 